\title{
Rapidly increasing migratory activity of Mongolian gazelle (Procapra gutturosa) and the sightings of Goitered gazelle (Gazella subgutturosa) in Transbaikalia as an alarm
}

\begin{abstract}
Vadim E. Kirilyuk
ABSTRACT. Mongolian gazelle (Procapra gutturosa) has been recovering in the Zabaikalsky Krai of Russia since 1993-1994. The process, supported by successful conservation measures, was slow at first, but then accelerated rapidly. Establishment of sedentary groups and increase of their abundance on the Russian territory took place with a simultaneous increase of seasonal migrations of transboundary groups. They became annual since 2008. Russian part of the range expanded from $260 \mathrm{~km}^{2}$ in 1998 to $29700 \mathrm{~km}^{2}$ in 2020 . It covers about $90 \%$ of habitats suitable for gazelle in the region. In 2019-2020, both the number of antelopes entering Russia and an area they occupy increased the most: not only antelopes wintered in Russia but they also expanded their occurrence on Russian territory during summer time which was unusual previously and led to a rapid increase of resident local groups. Also, barbed wire fence along a state border near the junction of Mongolia and China contributed to increased accumulation of antelopes on the Russian territory. An unusual entry of Goitered gazelle (Gazella subgutturosa) from Mongolia to Zabaikaisky Krai was first recorded in January 2020. The adult male was photographed near Solovyevsk station more than $500 \mathrm{~km}$ from the nearest part of its current range. My findings show that Mongolian gazelles rapidly concentrate in a disproportionately small part (4\%) of their current range i.e. the steppe part of Zabaikalsky krai of Russia. This concentration increases a probability of human-wildlife conflicts in Russia. Moreover, given the limited area of the suitable habitats and large number of natural and artificial barriers, chances of mass mortality among migrating cross-border groups increase dramatically. The observed processes evidence anthropogenic displacement of ungulates from the Mongolian territory due to a growing depletion of the forage supply and other negative drivers. In particular, climate change can increase the dangerous impact of humans. There is an urgent need to implement effective measures for conservation of Mongolian gazelle, based on regular monitoring of populations' parameters that serve as indicators of their sustainability.
\end{abstract}

How to cite this article: Kirilyuk V.E. 2021. Rapidly increasing migratory activity of Mongolian gazelle (Procapra gutturosa) and the sightings of Goitered gazelle (Gazella subgutturosa) in Transbaikalia as an alarm // Russian J. Theriol. Vol.20. No.1. P.25-30. doi: 10.15298/rusjtheriol.20.1.04.

KEY WORDS: Procapra gutturosa, Gazella subgutturosa, Transbaikalia, trans-boundary migration, longrange dispersal.

Vadim E. Kirilyuk [vkiriliuk@bk.ru], A.N. Severtsov Institute of Ecology and Evolution Russian Academy of Sciences, 33, Leninskii prospect, Moscow 119071, Russia; Daursky State Nature Biosphere Reserve, 76, Komsomolskaya str., Nizhniy Tsasuchey, Zabaikalsky krai 674480, Russia; Institute of Natural Resources, Ecology and Cryology Siberian Branch of Russian Academy of Sciences, 16a, Nedorezova str., Chita 672002, Russia.

\section{Быстро растущая миграционная активность дзерена (Procapra gutturosa) и появление джейрана (Gazella subgutturosa) в Забайкалье как повод для тревоги}

\section{В.Е. Кирилюк}

РЕЗЮМЕ. Монгольский дзерен (Procapra gutturosa) восстанавливается в пределах Забайкальского края России начиная с 1993-1994 гг. Процесс, поддержанный мощными природоохранными мерами, сначала происходил медленно, но затем резко ускорился. Формирование и увеличение численности на российской территории оседлых группировок происходило при параллельном нарастании сезонных миграций трансграничных группировок, ставшими ежегодными с 2008 г. Забайкальский очаг ареала

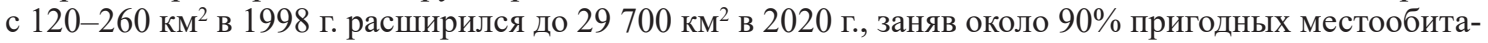
ний дзерена в регионе. В 2019-2020 гг. область распространения, а также численность заходящих в пределы России антилоп увеличились особенно сильно. Зимовки дзеренов в последние два года сопровождались нехарактерным для большинства предыдущих лет массовым расселением части 
особей на российской территории, что привело к стремительному росту численности оседло живущих местных группировок. Повышенное накопление антилоп на российской территории частично связано с наличием проволочных ограждений на участке государственной границы вблизи стыка Монголии и Китая. В январе 2020 г. впервые зафиксирован необычный заход из Монголии в Забайкальский край и Россию в целом джейрана (Gazella subgutturosa). Взрослый самец сфотографирован вблизи ст. Соловьевск на удалении более 500 км от ближайшего очага современного ареала. Продемонстрировано, что дзерен быстро концентрируется в несоразмерно малой части (4\%) современного ареала — в пределах степной части Забайкальского края России. Это усиливает социально-экономическое недовольство дзереном в российском регионе и, в условиях ограниченной площади пригодных местообитаний и наличия большого числа естественных и искусственных преград, резко повышает угрозу массовой гибели в мигрирующих трансграничных группировках. Наблюдающиеся процессы могут быть признаками антропогенного вытеснения копытных с территории Монголии, происходящими по причине нарастающего истощения кормовой базы и накопления других факторов негативного воздействия. Происходящие климатические изменения могут усилить опасное воздействие антропогенных факторов. Требуется срочное внедрение действенных мер сохранения дзерена, включающее трансграничные проблемы и основанное на выявлении свойственных виду мигрирующих и оседлых группировок и регулярном мониторинге параметров, служащих индикаторами их устойчивости.

КЛЮЧЕВЫЕ СЛОВА: Procapra gutturosa, Gazella subgutturosa, Забайкалье, трансграничные миграции, дальнее расселение.

\section{Introduction}

Mongolian gazelle, Procapra gutturosa (Pallas, 1777), and Goitered gazelle, Gazella subgutturosa (Guldenstaedt, 1778) are representatives of the Bovidae family, and inhabit open, arid areas of Central Asia. Mongolian gazelle has a stable population of 500000 1500000 individuals (IUCN SSC Antelope Specialist Group, 2016). Goitered gazelle is a vulnerable species, its population is decreasing, and is estimated at 42000 49000 individuals (IUCN SSC Antelope Specialist Group, 2017). Both species inhabit predominantly flat grounds of Central Asia but Goitered gazelle have a much larger range than Mongolian gazelle. However, Mongolian gazelles prefer wet habitats over the steppe biome, and Goitered gazelles prefer drier desert habitats. At the same time, dzerens can occupy desert habitats, too, and black-tailed gazelles can be sighted in dry steppes (Bannikov, 1954; Zhirnov, 1982; Lkhagvasuren \& Milner-Gulland, 1997).

This paper describes very high migratory activity of Mongolian gazelles and their dispersal in Zabaikalsky Krai, Russia, and the unusual long-distance Goitered gazelle migration beyond their historical range. These observations speak for the catastrophic processes resulting from aridization and gazelles' habitat disturbance under human influence. Unfortunately, population dynamic of Mongolian gazelle has been only rarely studied (Tsagaan, 1980; Sokolov et al., 1982; Lhagvasuren \& Milner-Gulland, 1997; Olson et al., 2005), and nothing is known about the population space-time structure. The purpose of this report is drawing attention to the dangerous processes that have not attracted the attention of the environmental community yet, and facilitate organization of a long-term system to monitor population parameters, analyze population changes and take timely and effective measures to preserve the Mongolian and Goitered gazelles.

\section{Material and methods}

I studied distribution, movement, abundance, and biology of Mongolian gazelle in 1993-2019. The study area included the steppe zone of two north-eastern provinces of Mongolia: Dornod and Khentey and the steppe region of Zabaikalsky Krai, Russia, inhabited by the so-called North Kherlen population of the species (Kirilyuk, 2007). I conducted surveys 2-3 times per year following transects covering gazelle habitats for totally more than $200000 \mathrm{~km}$ in Mongolia and more than $300000 \mathrm{~km}$ in Russia. I also used records by other biologists, nature conservation rangers, shepherds and other involved persons who work or live in the study area. Gazelles and records of their excrements were recorded using global geographical positioning system (GPS). I also mapped calving sites, main migration routes, and winter boundaries of the North Kherlen population (Kirilyuk \& Tsaveenmyadag, 1999; Kirilyuk \& Lushchekina, 2003; Kirilyuk et al., 2008; Kirilyuk et al., 2012).

For the total number of Mongolian gazelles, I used the annual census results conducted in September, when animals migrating from Mongolia are absent in the study area (Kirilyuk \& Lushchekina, 2017). To count migrating gazelles, similar surveys were conducted during winters in the areas of high population density. To estimate a number of Mongolian gazelles in the areas of low population density, I used a transect method (Caughley, 1979) and followed transects by a car counting a number of individuals in each observed herd. The total population in wintertime was estimated by extrapolation of survey results on non-surveyed areas of different population densities. Because extrapolation like this involves assumptions about areas of various population densities, and population density, in turn, is estimated as a certain range rather than a single value, we used minimum estimations resulting in conservative assessment of 
animal numbers. Therefore, reported numbers of winter migrants is a minimum estimate.

Occurrence of the Goitered gazelle within Russia at the long distance from its reported range border was confirmed by visual observations and photo registrations.

I conducted GIS analysis in NextGIS QGIS 17.7.0.

\section{Results}

\section{Mongolian gazelle}

Mongolian gazelle's geographic range have been increasing dramatically during 1998-2020 (Fig. 1). I described four stages of Mongolian gazelle dispersal changes and mapped the Russian part of their range at each stage: first stage 1998 describes gazelle geographic range before the rapid northward expansion; second stage 2000 when the first migration burst was fixed; third stage 2010 describes the events of irregular northward migration of gazelles; fourth stage 2020 when the high increase of migration activity was fixed.

Mongolian gazelles occupied $120-260 \mathrm{~km}^{2}$ between 1993 and 1998; only few dozen animals entered on Russian territory during warm seasons. The geographical area size of 2000 year reflected the results of two first season migrations into Russian territory. The irregular migrations of 2000-2010 shifted the species range boundaries even further up north within Russian territories (Kirilyuk, 2001, 2003, 2007; Kirilyuk et al., 2008; Kirilyuk \& Lushchekina, 2017). During 2019-2020 the largest expansion of the Russian part of Mongolian gazelle's range took place. In the winter of 2018-2019 were fixed the most numerous migrations of Mongolian gazelle to Southeast Transbaikalia in the last hundred years. In 2019 the gazelles occupied more than $29700 \mathrm{~km}^{2}$ (Fig. 1). Not all animals returned to Mongolia in the spring of 2019 after wintering in the region; herds of few dozen to few hundred animals occurred in suitable habitat during the summer. In winter of 2020 the gazelle migrations into Russia repeated with a similar intensity and remoteness. After noted migrations of 2019 and 2020 on Russian territories remained thousands of gazelles that determined a double growth of existing local groups and the formation of new groups (Fig. 2). I need to say that independently to the last years' migration activity the number of local groups had been rapidly increasing due to reproduction, especially thanks to the 25-year period of the species recovering in Russia. Three additional rapid increasing of the number occurred, and they were due to the additional resettlement of gazelles from Mongolia (Fig. 2). Significant Mongolian gazelle numbers increasing withing Russian territories fixed in May 2008 due to drought. The next numbers increasing fixed after the calving period in July 2017, when summer habitats in Mongolia were burnt by wildfires. In 2019 and 2020 the gazelle numbers increasing can determine as a result settling down of the animals after wintering. In last two years, seasonal migration turned into extensive relocation of Mongolian gazelles from the current part of their geographical range in Mongolia to the historical part of the range in Russian Transbaikalia.

\section{Goitered gazelle}

In December 2019-January 2020, two animals independently from each other were observed up north of the Russian-Mongolian border near Solovievsk railway station, Zabaikalsky Krai. One of them, an adult male, was photographed on January 11, 2020 (ca. $49.93^{\circ} \mathrm{N}$ $\left.112.867^{\circ} \mathrm{E}\right)$ (Fig. 3), on a sod field with well-preserved dead grass in a forb-feather steppe. In the following days, the gazelle was observed several times on the Mongolian territory, down south from the RussianMongolian border.

\section{Discussion}

Mongolian gazelles increase winter migrant number and their range size within Russia very rapidly. More and more gazelles down settled on Russian territories after winter migrations, especially in 2019-2020 (Fig. 2). This migration activity together with a Russian Mongolian gazelle conservation program helped restore the Transbaikal part of the species' range, previously totally lost due to human activity. The changes of the species northern boundary In Transbaikalia are associated with cyclical changes in precipitation and clearly display natural pulsations of range boundaries (Kirilyuk et al., 2012). Nevertheless, I determine the rapid expansion of Mongolian gazelle into Russian Transbaikalia as an abnormal. Population density of Mongolian gazelles in Russia is disproportionately high as compared to other parts of their range. The current range of Mongolian gazelle in Mongolia was estimated as $517952 \mathrm{~km}^{2}$ in 2009 (Adiay et al., 2019), and increased by at least $30000 \mathrm{~km} 2$ after 2009 (Kirilyuk, unpublished data). Expansion to Transbaikalia over the past 20 years has increased the range by $29700 \mathrm{~km} 2$, of which about $24000 \mathrm{~km}^{2}$ are suitable habitats for Mongolian gazelle. Hence, the Russian part of Mongolian gazelle's range is about $4 \%$ of the total current species' range, but as of 2019 , it is used by $12-14 \%$ of the total population size, if we estimate the current numbers of Mongolian gazelles as approximately 1000000 individuals.

The sighting meeting point of the Goitered gazelle was located in $540 \mathrm{~km}$ from a border of its current range (Adiay et al., 2019). Long-term drought and overgrazing in 2000-2019 in North-East Mongolia have turned the steppe habitats in an almost grassless area (Kirilyuk, unpubl.) that visually similar to a desert or semi-desert habitat and may be more comfort for Goitered gazelle. The general direction of the Goitered gazelle migration into the Torey depression is potentially possible through lowest and driest territories, present migration routes of Mongolian gazelle, or guided by artificial linear barriers such as Choibalsan-Borzya railway and fences along the Chinese border. There is only the Kerulen River in Mongolia as an insignificant barrier on the gazelle migration routes due to the small flow of water either in winter or summer.

Rapid growth of the shift of Mongolian gazelle from Mongolia to Russia is alarming. This process includes a 


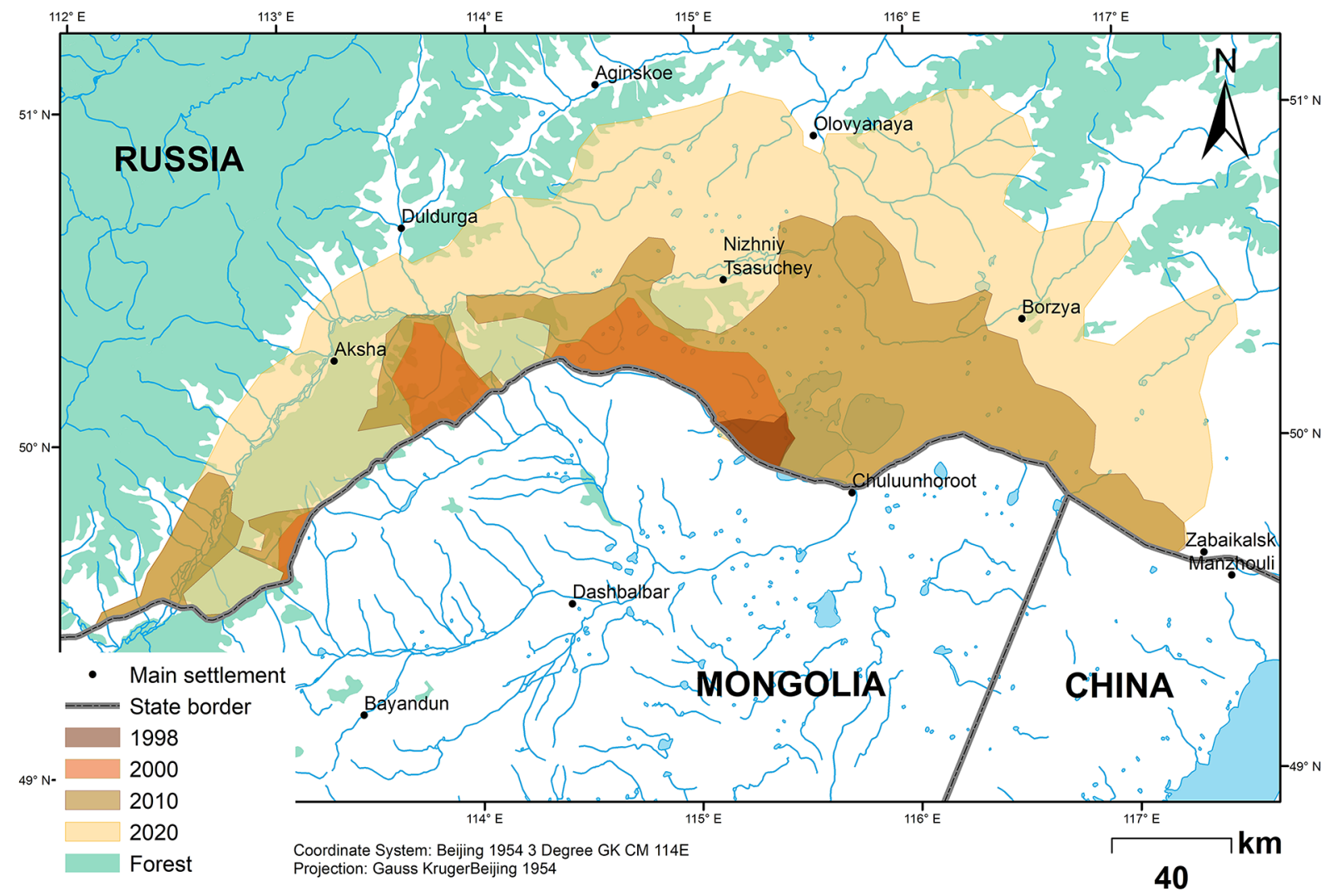

Fig. 1. Expansion of Mongolian gazelle range throughout Russian Transbaikalia in 1998-2020; observation of the Goitered gazelle in 2020 .

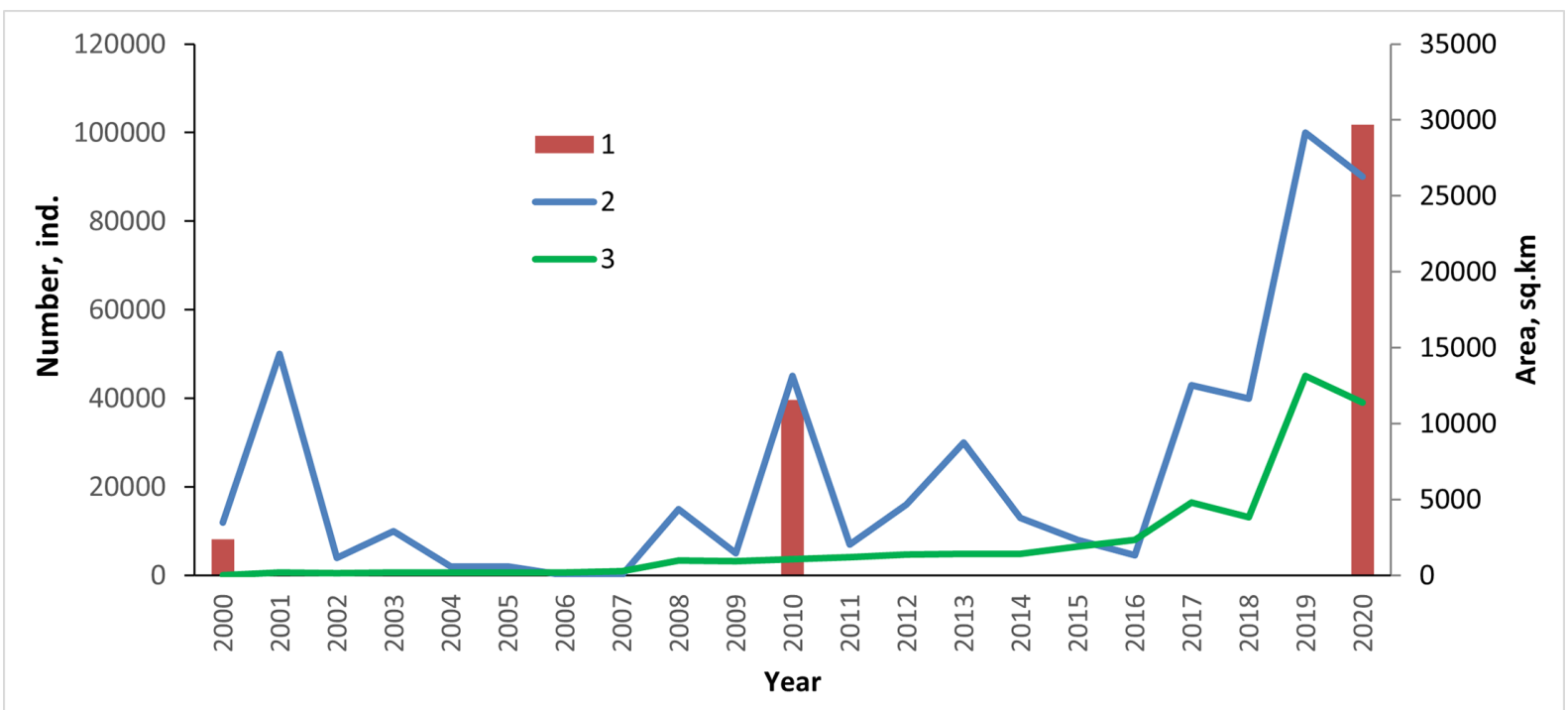

Fig. 2. Changes of the range area (1), number of wintering (2) and local (3) Mongolian gazelles in Transbaikalia (2000-2020).

growing number of intensive migrations, and even more importantly an increasing number of animals settling in Transbaikalia. In addition, accumulation of Mongolian gazelles in Russia is partly determined by a barbed-wire border construction that locates between the Torey Lakes to the Zabaikalsk City (Fig. 1). This construction acts as a one-way valve that prevents some gazelle herds from crossing the state border between Russian and Mongolia during spring back migration.

To evaluate factors that can explain the increasing migration of Mongolian gazelles and occurrence of Goitered gazelles in Russian Transbaikalia we need 


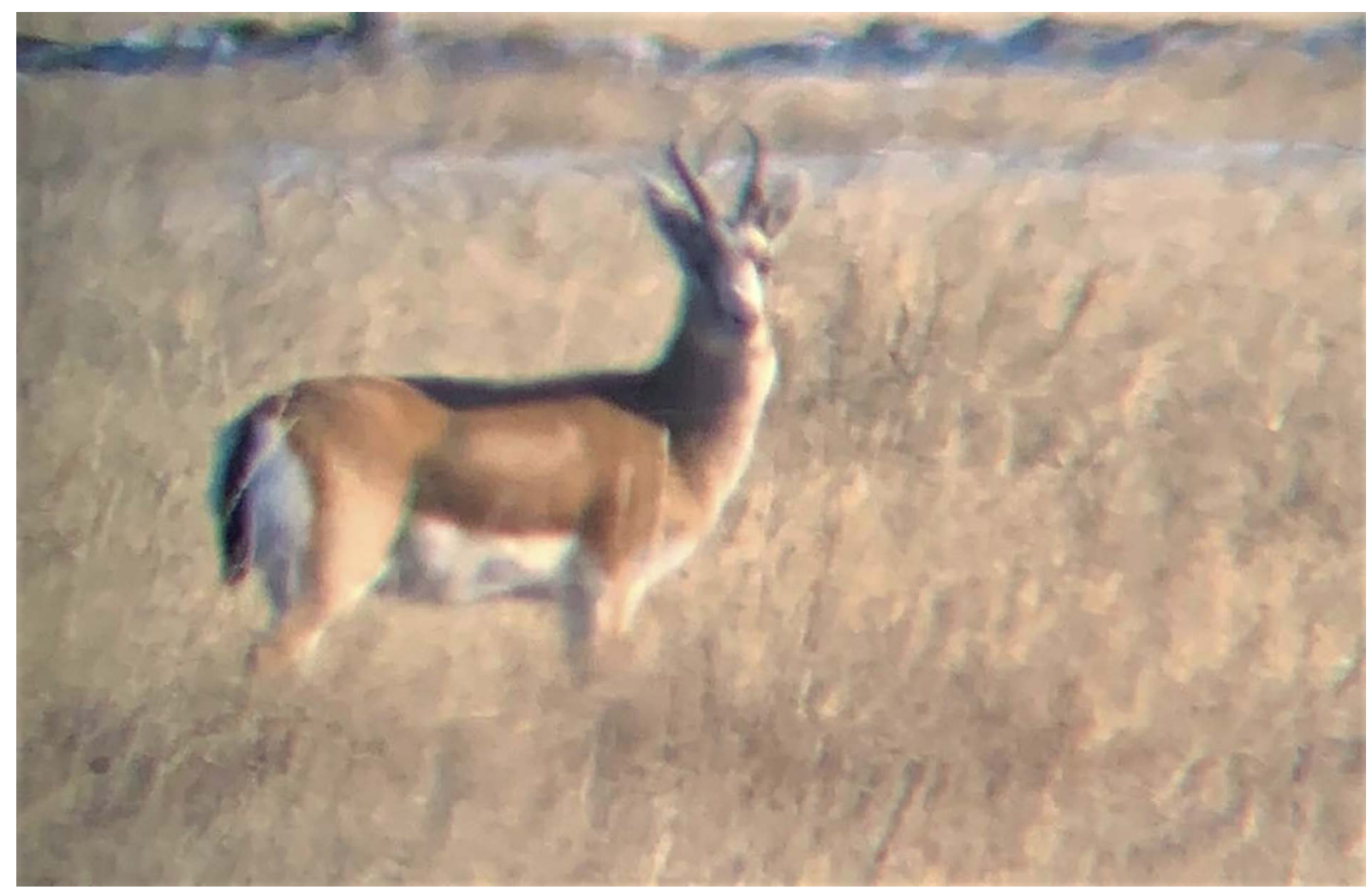

Fig. 3. Adult male of Goitered gazelle in Transbaikalia, Solovievsk, 11 January $2020,49.93^{\circ} \mathrm{N}, 112.867^{\circ} \mathrm{E}$, photo by Petr Khramov.

to assess forage supply for wild ungulates. Habitats of both species in Mongolian territories underwent a striking change with the loss of feeding ability as a result of droughts and overgrazing by livestock, which numbers increasing from 30000000 to 71000000 animals between in 2000 and 2019 (Mongolian Statistical Information Service). Another factor is the disturbance of Mongolian gazelles by people and domestic dogs. This influence lesser in Zabaikalsky Kray than in Mongolia (Kirilyuk, unpubl.) that supposedly can also determine gazelle expansion from Mongolia into Russia. The emerging signs of the rapid relocation of the Mongolian gazelle into Russia is a great threat to transboundary migratory groups and may be a harbinger of the global population's vulnerability. Development of monitoring system to track the main population parameters and adoption of long-term conservation measures are extremely urgent.

ACKNOWLEDGEMENTS. The author is greatly grateful to the staff of the Daursky Nature Reserve, rangers and drivers, who provide invaluable assistance in many years of work. The author is also grateful to A.V. Kirilyuk for help with the map preparation. The work was carried out within the framework of the Program of Fundamental Research of the Russian Academy of Sciences, project No 121032200126-6. The study was performed with financial support from the Russian Foundation for Basic Research (grant No. 20-04-00448).

\section{References}

Bannikov A.G. 1954. [Mammals of the Mongolian People's Republic]. Moscow: Nauka. 669 p. [in Russian]

Adiya Ya., Amarjargal B., Amelina T.V., Andreev A.V., Ariunbold E., et al. 2019. Ecosystem of Mongolia. Ulaanbaatar: Admon. 264 p.

IUCN SSC Antelope Specialist Group 2016. Procapra gutturosa (errata version published in 2017) // The IUCN Red List of Threatened Species 2016: e.T18232A115142812. https:// dx.doi.org/10.2305/IUCN.UK.2016-3.RLTS. T18232A50193126.en. Downloaded on 06 April 2020.

IUCN SSC Antelope Specialist Group 2017. Gazella subgutturosa // The IUCN Red List of Threatened Species 2017: e.T8976A50187422. https://dx.doi. org/10.2305/IUCN.UK.2017-2.RLTS.T8976A50187422. en. Downloaded on 06 April 2020.

Caughley G. 1979. [Analyzing of vertebrate populations]. Moscow: Mir. 362 p. [in Russian]

Kirilyuk V.E. 2001. Current migrations of Mongolian Gazelle (Procapra gutturosa) in Trans-Baikal Region // Proceedings of the Zoological Institute of RAS. No.288. P.136-153. [in Russian]

Kirilyuk V.E. 2003. Restoration of Dzeren in Russia - first successes // Terrestrial vertebrates of Dauria. Proceedings of the Daurian Reserve. Vol.3. P.76-102. [in Russian, with English summary] 
Kirilyuk V.E. 2007. [The first results and prospects for the restoration of the Mongolian gazelle (Procapra gutturosa) in Russia]. Chita: Express-Publishing House. 36 p. [in Russian].

Kirilyuk V.E. \& Cherepitsin A.A., 1998. Mongolian gazelle in the South-Eastern Transbaikalia // Bulletin of Moscow Society of Naturalists. Biological series. Vol.103. P.21-25. [in Russian]

Kirilyuk V.E., Kirilyuk O.K., Faleychik L.M. \& Borodina T.A. 2008. Analysis of the spatiotemporal structure of the Mongolian gazelle population in the Northeastern Mongolia // Collection of reports of the international scientific-practical conference "Cross-border cooperation: Russia, China, Mongolia”. 22-25 October 2008 г. Chita. P.138-144. [in Russian]

Kirilyuk V.E. \& Lushchekina A.A. 2003. Mongolian gazelle on the range north: historical review, present migration and dispersal, prospects for species recovery in Russia//Janchiv Ts. (ed.). Mammalogical studies in Mongolia and its adjacent territories: Proceedings of the Institute of Biology. Ulaanbaatar. No.24. P.77-84. [in Russian, with English summary]

Kirilyuk V.E. \& Lushchekina A.A. 2017. Current status of Procapra gutturosa (Bovidae) in Russia // Nature Conservation Research. Vol.2. Suppl.1. P.81-99. [In Russian, with English summary]

Kirilyuk V.E., Obyazov V.A., Tkachuk T.E. \& Kirilyuk O.K 2012. Influence of Climate Change on Vegetation and Wildlife in the Daurian Eco-region // Werger M.J.A. \& van Staalduinen M.A. (eds.). Eurasian Steppes. Ecological Problems and Livelihoods in a Changing World. N.Y.-London: Springer Dordrecht Heidelberg. P.397-424.
Kirilyuk V.E. \& Paltsyn M.Yu. 2019. Modeling of Mongolian gazelle habitats and forecasted limits for restoration of the range and number in Transbaikalia // Behavior and behavioral ecology of mammals. Materials of the 4th scientific conference (Chernogolovka, November 11-15, 2019). Moscow: Partnership of scientific publications. P.30. [in Russian] Kirilyuk V.E. Tseveenmyadag N. 1999. Spatial-temporal structure of Mongolian gazelle populations in the lower river Uldz (Northeastern Mongolia) // Rare species of mammals in Russia and adjacent territories. Moscow. P.154-167. [in Russian]

Lkhagvasuren B. \& Milner-Gulland E. 1997. The status and management of the Mongolian gazelle Procapra gutturosa population // Oryx. Vol.31. No 2. P.127-134.

Mongolian Statistical Information Service. Apr. 2020 https:// www.en.nso.mn

Olson K.A., Fuller T.K., Schaller G.B., Odonkhuu D. \& Murray M.G 2005. Estimating the population density of Mongolian gazelles Procapra gutturosa by driving long-distance transects // Oryx Vol.39. P.164-169.

Sokolov V.E., Dash Ya., Lushchekina A.A. \& Neronov V.M. 1982. Modern distribution and quantitative placement of Mongolian gazelle in Mongolian People's Republic // Sokolov V.E. (ed.). Zoological studies in MPR. Moscow: Nauka. P.7-20. [in Russian]

Tsagaan S. 1980. Current range, number and main migration directions of Mongolian gazelle (Gazella gutturosa Gmel.) // Proceedings of the Institute of General and Experimental Biology. No.15. P.128-139.

Zhirnov L.V. 1982. [Returned to life]. Moscow: Forest industry. 224 p. [in Russian] 